\title{
AKTIVITAS ANTIBAKTERI SARI BUAH BELIMBING WULUH (Averrhoa bilimbi Linn.) TERHADAP BAKTERI PSEUDOMONAS AERUGINOSA DAN STAPHYLOCOCCUS EPIDERMIDIS
}

\author{
Jeryanti Tandi Datu ${ }^{1, *}$, Nur Mita ${ }^{1}$, Rolan Rusli ${ }^{1,2, \dagger}$ \\ ${ }^{1}$ Laboratorium Penelitian dan Pengembangan Kefarmasian "Farmaka Tropis", \\ Fakultas Farmasi, Universitas Mulawarman, Samarinda \\ *Email : jetadamb@yahoo.com \\ ${ }^{2}$ Program Studi Pendidikan Kimia, Fakultas Keguruan dan Ilmu Pendidikan, \\ Universitas Mulawarman, Samarinda \\ †Email: rolan@farmasi.unmul.ac.id
}

\begin{abstract}
Bilimbi (Averrhoa bilimbi Linn.) has been used traditionally to treat diseases such as skin rash allergic on the face, boils, and pimples. Active component in this fruit such as flavonoids, tannins and saponins, theoretically are effective as an antibacterial. This research is to determine the antibacterial activity of bilimbi. The determine of antibacterial activity is carried out by using agar diffusion methods with five concentrations were 25\%, 37.5\%, 50\%, 62.5\% and 75\%, respectivelly. The results showed that bilimbi juice has inhibited test bacterial growth. The best concentration antibacterial activity was $75 \%$. Antibacterial potency of bilimbi juice towards Pseudomonas aeruginosa and Staphylococcus epidermidis was very significant to the positive control of amoxicillin.
\end{abstract}

Keywords: Antibacterial activity, Agar diffusion, Averrhoa bilimbi L., Pseudomonas aeruginosa, Staphylococcus epidermidis

\begin{abstract}
ABSTRAK
Buah belimbing wuluh (Averrhoa bilimbi Linn.) secara tradisional telah digunakan untuk mengobati penyakit alergi pada kulit seperti ruam pada wajah, bisul dan jerawat. Zat aktif yang terkandung dalam tanaman tersebut antara lain flavonoid, tannin dan saponin yang berkhasiat sebagai antibakteri. Oleh karena itu, dilakukan uji aktivitas antibakteri dari sari buah belimbing wuluh (Averrhoa bilimbi L.). Pengujian antibakteri menggunakan metode difusi agar dengan konsentrasi $25 \%$, $37,5 \%, 50 \%, 62,5 \%$ dan 75\%. Hasil penelitian menunjukkan bahwa sari buah belimbing wuluh memiliki aktivitas sebagai antibakteri. Konsentrasi terbaik dalam menghambat pertumbuhan bakteri uji Pseudomonas aeruginosa dan
\end{abstract}


Staphylococcus epidermidis adalah $75 \%$. Potensi antibakteri sari buah belimbing wuluh terhadap bakteri Pseudomonas aeruginosa dan Staphylococcus epidermidis adalah sangat signifikan terhadap kontrol positif amoksisilin.

Kata Kunci: Aktivitas Antibakteri, Difusi agar, Averrhoa bilimbi L, Pseudomonas aeruginosa, Staphylococcus epidermidis.

\section{PENDAHULUAN}

Buah belimbing wuluh (Averrhoa bilimbi Linn.) secara tradisional telah digunakan untuk mengobati penyakit alergi pada kulit seperti ruam pada wajah, bisul dan jerawat. Kajian etnobotani buah belimbing wuluh sebagai tanaman obat telah dilakukan di Kabupaten Pidie [1]. Zat aktif yang terkandung dalam tanaman tersebut antara lain flavonoid, tannin dan saponin yang berkhasiat sebagai antibakteri [2]. Adanya kandungan senyawa tersebut, diharapkan buah belimbing wuluh dapat menghambat atau membunuh perkembangbiakan bakteri Pseudomonas aeruginosa dan Staphylococcus epidermidis, dimana bakteri Pseudomonas aeruginosa merupakan bakteri Gram negatif yang dapat masuk ke dalam jaringan tubuh dan menimbulkan gejala penyakit bila pertahanan tubuh yang normal terganggu. Karena itu bakteri tersebut sering masuk ke dalam jaringan yang terkena luka atau luka bakar yang akan menimbulkan infeksi bernanah berwarna hijau-biru [3]. Kemudian Staphylococcus epidermidis merupakan bakteri Gram positif yang merupakan flora normal pada kulit manusia, saluran pernapasan dan saluran pencernaan [4]. Bakteri ini merupakan penyebab infeksi kulit yang ringan yang disertai pembentukan abses [5]. Berdasarkan uraian di atas, maka akan dilakukan uji aktivitas antibakteri sari buah belimbing wuluh terhadap bakteri Pseudomonas aeruginosa dan Staphylococcus epidermidis.

\section{METODE PENELITIAN}

\section{Bahan}

Bahan yang digunakan dalam penelitian ini adalah buah belimbing wuluh, aquades, bakteri uji Pseudomonas aeruginosa dan Staphylococcus epidermidis, medium Nutrient Agar (NA) (Merck, 1.05450), NaCl 0,9\% (Widatra), paper disc atau kertas saring (Whatman no 42), dan antibiotik amoksisilin.

\section{Peralatan}

Peralatan yang digunakan dalam penelitian ini antara lain vial, hot plate, timbangan analitik, cawan porselin, labu ukur, tabung reaksi, autoklaf, inkubator, cawan petri, erlenmeyer, spoit injeksi, LAF (laminar air flow), juicer, mikrometer, dan alat penunjang lainnya. 


\section{Prosedur Penelitian}

Sebelum dilakukan pengujian aktivitas antibakteri, terlebih dahulu dilakukan sterilisasi semua alat dan bahan yang digunakan dalam autoklaf pada suhu $121{ }^{\circ} \mathrm{C}$ selama 15 menit. Mikroba uji ditanamkan di atas permukaan media NA metode agar miring yang telah memadat dalam tabung reaksi dan diinkubasi pada inkubator selama 24 jam pada suhu $37{ }^{\circ} \mathrm{C}$. Setelah 24 jam dilakukan pengenceran pada bakteri uji dengan ditambahkan $\mathrm{NaCl} 0,9 \%$ hingga didapatkan pengenceran bakteri uji 1:40.

Pengujian aktivitas antibakteri sari buah belimbing wuluh dilakukan dengan metode difusi agar menggunakan medium NA. Dimasukkan 0,02 mL suspensi bakteri ke dalam botol pengencer kemudian ditambahkan $10 \mathrm{~mL}$ medium NA ke dalam botol pengencer dan dihomogenkan, lalu dituang campuran suspensi bakteri dan medium NA ke dalam cawan petri steril hingga setengah memadat. Paper disc direndam selama 15 menit di dalam masing-masing larutan uji sari buah belimbing wuluh (konsentrasi 25\%, 37,5\%, 50\%, 62,5\% dan 75\%), aquadest, dan antibiotik amoksisilin. Selanjutnya paper disc tersebut diletakkan pada medium dan diinkubasi selama $1 \times 24$ jam pada suhu $37^{\circ} \mathrm{C}$.

\section{HASIL DAN PEMBAHASAN}

Pengujian aktivitas antibakteri sari buah belimbing wuluh dilakukan dengan menggunakan berbagai tingkat konsentrasi. Konsentrasi yang digunakan yaitu $25 \%, 37,5 \%, 50 \%, 62,5 \%$ dan 75\% untuk bakteri Pseudomonas aeruginosa dan Staphylococcus epidermidis. Hasil pengujian aktivitas antibakteri sari buah belimbing wuluh dapat dilihat pada gambar 1 .
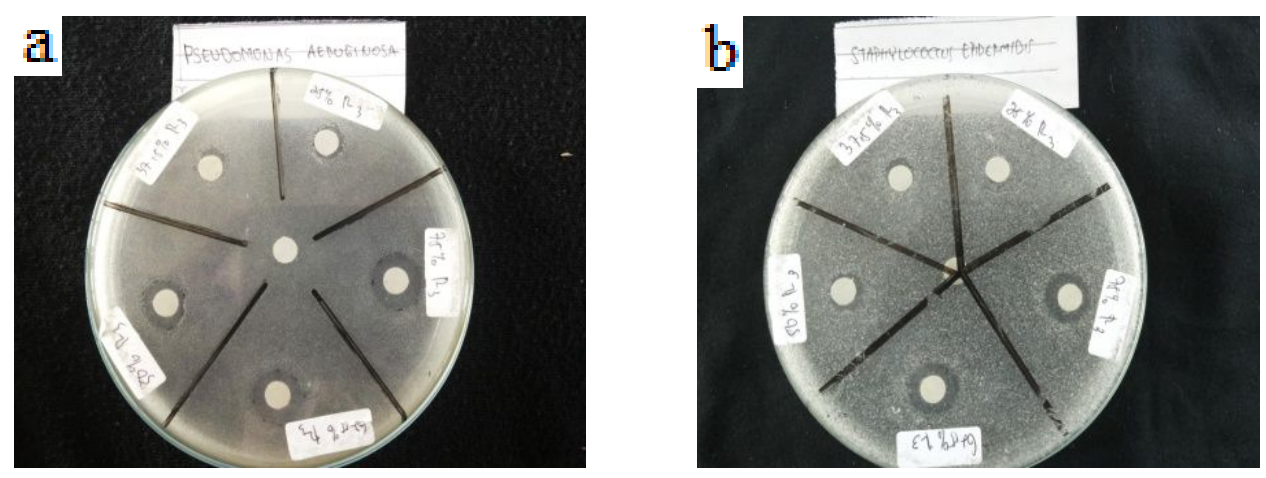

Gambar 1. Uji aktivitas antibakteri sari buah belimbing wuluh terhadap bakteri (a) Pseudomonas aeruginosa dan (b) Staphylococcus epidermidis.

Hasil penelitian menunjukkan bahwa sampel uji sari buah belimbing wuluh memiliki aktivitas antibakteri terhadap bakteri Pseudomonas aeruginosa dan Staphylococcus epidermidis yang ditandai dengan terbentuknya zona hambat di sekitar paperdisc seperti yang terlihat pada Gambar 1. Aktivitas antibakteri sari 
buah belimbing wuluh karena kandungan metabolit sekundernya seperti saponin, flavonoid, dan tanin yang dapat berperan sebagai aktivitas antibakteri [2]. Pada kontrol negatifnya (aquades) tidak terbentuk zona hambat di sekitar paperdisc sehingga dapat disimpulkan bahwa pelarut yang digunakan tidak mempengaruhi aktivitas antibakteri dari sampel uji, hal ini membuktikan bahwa aktivitas antibakteri merupakan aktivitas dari sari buah belimbing wuluh.

Terlihat pula adanya perbedaan aktivitas antibakteri pada masing-masing bakteri uji, dimana pada bakteri Staphylococcus epidermidis pada konsentrasi 25\% tidak terbentuk zona hambat di sekitar paperdisc sedangkan pada bakteri uji Pseudomonas aeruginosa terbentuk zona hambat di sekitar paperdisc. Data yang menunjukkan zona hambat yang terbentuk dari aktivitas sari buah belimbing wuluh dirangkumkan pada Tabel 1.

Tabel 1. Zona hambat yang terbentuk dari hasil aktivitas sari buah belimbing wuluh.

\begin{tabular}{cccc}
\hline Sampel Uji & Bakteri Uji & $\begin{array}{c}\text { Konsentrasi } \\
(\%)\end{array}$ & $\begin{array}{c}\text { Rerata Diameter Zona Hambat } \\
(\mathrm{mm})\end{array}$ \\
\hline & Pseudomonas & 25 & 2,57 \\
& aeruginosa & 37,5 & 2,98 \\
& & 50 & 4,52 \\
Sari Buah & 62,5 & 6,44 \\
Belimbing & 75 & 8,53 \\
Wuluh & Staphylococcus & 25 & 0 \\
& epidermidis & 37,5 & 2,16 \\
& & 50 & 2,81 \\
& & 62,5 & 4,37 \\
\hline Kontrol Negatif (Aquadest) & 75 & 6,11 \\
\hline
\end{tabular}

Tabel 1 menunjukkan bahwa semakin meningkat konsentrasi sampel uji maka semakin besar pula zona hambat yang terbentuk. Terlihat pada sari buah belimbing wuluh dengan konsentrasi $25 \%$ tidak dapat menghambat pertumbuhan bakteri Staphylococcus epidermidis tetapi dapat menghambat pertumbuhan bakteri Pseudomonas aeruginosa. Pada data diameter zona hambat yang terbentuk juga menunjukkan bahwa sari buah belimbing wuluh lebih efektif pada bakteri Gram negatif daripada bakteri Gram positif. Perbedaan aktivitas antibakteri dari masingmasing bakteri uji pada sari buah belimbing wuluh diduga karena adanya perbedaan struktur dinding sel bakteri pada kedua jenis bakteri tersebut. Dinding sel bakteri Gram positif terdiri atas beberapa lapisan peptidoglikan yang membentuk struktur yang tebal dan kaku serta mengandung substansi dinding sel yang disebut asam teikoat, sedangkan dinding sel bakteri Gram negatif terdiri atas satu atau lebih lapisan peptidoglikan yang tipis dan membran di bagian luar lapisan peptidoglikan. 
Karena hanya mengandung sedikit lapisan peptidoglikan dan tidak mengandung asam teikoat, maka dinding sel bakteri Gram negatif lebih rentan terhadap guncangan fisik, seperti pemberian antibiotik atau bahan antibakteri lainnya. [6]

\section{Konsentrasi Terbaik Sari Buah Belimbing Wuluh}

Konsentrasi terbaik sari buah belimbing wuluh yaitu konsentrasi yang memberikan aktivitas antibakteri paling besar dalam menghambat atau membunuh pertumbuhan bakteri ditunjukkan dengan adanya zona bunuh/hambat. Konsentrasi terbaik diperoleh dari data diameter zona hambat yang kemudian dianalisis menggunakan metode statistik anava satu arah dan dilanjutkan dengan uji lanjutan.

Hasil pengujian yang telah dilakukan menujukkan adanya aktivitas antibakteri sari buah belimbing wuluh yang terlihat dengan adanya zona hambat yang terbentuk di sekitar paperdisc. Pada kedua bakteri uji terlihat pada konsentrasi 75\% merupakan konsentrasi yang memiliki aktivitas paling besar dalam menghambat pertumbuhan bakteri. Data tersebut kemudian dianalisis menggunakan analisis varian (ANAVA) satu arah.

Berdasarkan analisis varian satu arah menunjukkan bahwa dari hasil $F_{h i t u n g}$ yang diperoleh memiliki hasil yang sangat signifikan dibandingkan dengan $\mathrm{F}_{\text {tabel }}$ $1 \%$ dan 5\%. Hal ini menunjukkan bahwa sari buah belimbing wuluh dengan 5 variasi konsentrasi memberikan pengaruh yang sangat signifikan atau sangat berbeda nyata karena memiliki $F_{\text {hitung }}$ yang lebih besar dibandingkan dengan $F_{\text {tabel. }}$.

Berdasarkan Hasil uji BNJD menunjukkan bahwa konsentrasi terbaik sari buah belimbing wuluh dalam menghambat pertumbuhan bakteri pada bakteri Pseudomonas aeruginosa dan Staphylococcus epidermidis adalah 75\%.

\section{Potensi Antibakteri Sari Buah BelimbingWuluh}

Potensi antibakteri sari buah belimbing wuluh adalah kemampuan sari buah dalam membunuh atau menghambat pertumbuhan bakteri uji yang dibandingkan dibandingkan dengan antibiotik. Antibiotik yang digunakan dalam penelitian ini adalah amoksisilin. Amoksisilin merupakan antibiotik dengan spektrum luas yang aktif terhadap bakteri Gram positif dan beberapa bakteri Gram negatif. Amoksisilin bekerja dengan cara menghambat sintesis dinding sel bakteri.

Potensi antibakteri diperoleh dari hasil pengujian aktivitas sari buah belimbing wuluh dan antibiotik amoksisilin terhadap bakteri Pseudomonas aeruginosa dan Staphylococcus epidermidis dengan konsentrasi yang berbeda. Data yang diperoleh dianalisis dengan menggunakan uji-t untuk mengetahui potensi antibakteri sari buah belimbing wuluh yang dibandingkan dengan antibiotik amoksisilin.

\section{Sari Buah Belimbing Wuluh Terhadap Bakteri Pseudomonas aeruginosa}

Data hasil diameter zona hambat antara sari buah belimbing wuluh dibandingkan dengan antibiotik amoksisilin terhadap bakteri Pseudomonas aeruginosa dapat dilihat pada Tabel 2. 
Tabel 2. Hasil zona hambat sari buah belimbing wuluh dan antibiotik Amoksisilin terhadap bakteri Pseudomonas aeruginosa

\begin{tabular}{cccc}
\hline $\begin{array}{c}\text { Konsentrasi } \\
(\%)\end{array}$ & $\begin{array}{c}\text { Diameter Zona } \\
\text { Hambat Sari Buah } \\
\text { Belimbing Wuluh } \\
(\mathrm{mm})\end{array}$ & $\begin{array}{c}\text { Konsentrasi } \\
(\%)\end{array}$ & $\begin{array}{c}\text { Diameter Zona Hambat } \\
\text { Amoksisilin }(\mathrm{mm})\end{array}$ \\
\hline 25 & 2,57 & 0,0125 & 9,14 \\
37,5 & 2,98 & 0,025 & 10,33 \\
50 & 4,52 & 0,05 & 11,75 \\
62,5 & 6,44 & 0,075 & 12,71 \\
75 & 8,53 & 0,1 & 12,90 \\
\hline
\end{tabular}

Tabel 2. menunjukkan bahwa diameter zona hambat yang dibentuk oleh sari buah belimbing wuluh lebih kecil dibandingkan dengan kontrol positif amoksisilin. Untuk membuktikan tingkat kebenaran dari data tersebut maka data hasil uji aktivitas antibakteri sari buah belimbing wuluh dan amoksisilin dilakukan analisis uji-t yang bertujuan untuk membandingkan potensi antibakteri sari buah belimbing wuluh dengan antibiotik amoksisilin. Hasil analisis uji-t antara sari buah belimbing wuluh dengan amoksisilin terhadap bakteri uji Pseudomonas aeruginosa diperoleh nilai $\mathrm{T}_{\text {hitung }}$ lebih besar $(4,78)$ dari $\mathrm{T}_{\text {tabel }} 5 \%(3,355)$ dan $\mathrm{T}_{\text {tabel }} 1 \%(2,306)$. Hal ini berarti sangat signifikan atau sangat berbeda nyata. Dengan demikian menunjukkan bahwa potensi antibiotik amoksisilin lebih baik dibandingkan dengan potensi sari buah belimbing wuluh dalam menghambat pertumbuhan bakteri Pseudomonas aeruginosa.

\section{Sari Buah Belimbing Wuluh Terhadap Bakteri Staphylococcus epidermidis}

Data hasil diameter zona hambat antara sari buah belimbing wuluh dibandingkan dengan antibiotik amoksisilin terhadap bakteri Staphylococcus epidermidis dapat dilihat pada Tabel 3.

Tabel 3. Hasil zona hambat sari buah belimbing wuluh dan antibiotik Amoksisilin terhadap bakteri Staphylococcus epidermidis

\begin{tabular}{cccc}
\hline $\begin{array}{c}\text { Konsentrasi } \\
(\%)\end{array}$ & $\begin{array}{c}\text { Diameter Zona Hambat } \\
\text { Sari Buah Belimbing } \\
\text { Wuluh }(\mathrm{mm})\end{array}$ & $\begin{array}{c}\text { Konsentrasi } \\
(\%)\end{array}$ & $\begin{array}{c}\text { Diameter Zona Hambat } \\
\text { Amoksisilin }(\mathrm{mm})\end{array}$ \\
\hline 25 & 0 & 0,0125 & 10,57 \\
37,5 & 2,16 & 0,025 & 11,26 \\
50 & 2,81 & 0,05 & 12,83 \\
62,5 & 4,37 & 0,075 & 13,64 \\
75 & 6,11 & 0,1 & 13,94 \\
\hline
\end{tabular}


Tabel 3. menunjukkan bahwa diameter zona hambat yang dibentuk oleh sari buah belimbing wuluh lebih kecil dibandingkan dengan kontrol positif amoksisilin. Untuk membuktikan tingkat kebenaran dari data tersebut maka data hasil uji aktivitas antibakteri sari buah belimbing wuluh dan amoksisilin dilakukan analisis uji-t yang bertujuan untuk membandingkan potensi antibakteri sari buah belimbing wuluh dengan antibiotik amoksisilin. Hasil analisis uji-t antara sari buah belimbing wuluh dengan amoksisilin terhadap bakteri uji Staphylococcus epidermidis diperoleh nilai $\mathrm{T}_{\text {hitung }}$ lebih besar $(5,96)$ dari $\mathrm{T}_{\text {tabel }} 5 \%(3,355)$ dan $\mathrm{T}_{\text {tabel }} 1 \%(2,306)$ yang berarti sangat signifikan atau sangat berbeda nyata. Hal ini menunjukkan bahwa potensi antibiotik amoksisilin lebih baik dibandingkan dengan potensi sari buah belimbing wuluh dalam menghambat pertumbuhan bakteri Staphylococcus epidermidis.

\section{KESIMPULAN}

Sari buah belimbing wuluh memiliki aktivitas sebagai antibakteri terhadap bakteri Pseudomonas aeruginosa dan Staphylococcus epidermidis. Konsentrasi terbaik sari buah belimbing wuluh sebagai antibakteri terhadap bakteri Pseudomonas aeruginosa dan Staphylococcus epidermidis yaitu pada konsentrasi $75 \%$. Terdapat perbedaan potensi antibakteri antara sari buah belimbing wuluh dengan kontrol positif amoksisilin yang digunakan memiliki potensi antibakteri sari buah belimbing wuluh lebih rendah dibandingkan dengan kontrol positif Amoksisilin sebagai antibakteri.

\section{DAFTAR PUSTAKA}

[1] Nursanty, Risa dan Zumaidar. 2010. Potensi Antibakteri Beberapa Tumbuhan Obat Tradisional. Jurnal Biologi Edukasi 2 (3): 1.

[2] Wijayakusuma, Hembing. 2008. Ramuan Herbal Penurun Kolesterol. Pustaka Bunda: Jakarta.

[3] Entjang, I. 2003. Mikrobiologi dan Parasitologi. PT. Citra Aditya Bakti: Bandung.

[4] Jawetz, dkk. 1996. Mikrobiologi Kedokteran. EGC: Jakarta

[5] Anonim. 1993. Buku Ajar Mikrobiologi Kedokteran Edisi Revisi. Binarupa Aksara: Jakarta.

[6] Radji, M. 2011. Mikrobiologi. Buku Kedokteran ECG: Jakarta. 